\title{
Detection of cytomegalovirus in an immunocompetent adult presenting with acute retinal necrosis due to varicella-zoster virus:
}

\section{a case report}

\author{
Tomoko Nakamura' \\ Tohru Daikoku² \\ Kimiyasu Shiraki² \\ Atsushi Hayashi' \\ 'Department of Ophthalmology, \\ ${ }^{2}$ Department of Virology, Graduate \\ School of Medicine and Pharmaceutical \\ Sciences, University of Toyama, Toyama, \\ Japan
}

Correspondence: Atsushi Hayashi Department of Ophthalmology, Graduate School of Medicine and Pharmaceutical Sciences, University of Toyama, 2630 Sugitani, Toyama 930-0194, Japan

Tel +8I 764347363

Fax +8I 764345037

Email ahayashi@med.u-toyama.ac.jp

\author{
This article was published in the following Dove Press journal: \\ Clinical Ophthalmology \\ 13 May 2015 \\ Number of times this article has been viewed
}

Background: To report a case of simultaneous detection of cytomegalovirus (CMV) in acute retinal necrosis (ARN) due to varicella-zoster virus (VZV) in an immunocompetent adult.

Methods: A 65-year-old healthy woman presented with necrotizing retinitis. Vitreous, tears, saliva, and swabs of the auricular and forehead skin areas were collected and tested by polymerase chain reaction analysis at various time points during the treatment period.

Results: VZV and CMV DNA were detected in the vitreous, tears, saliva, and skin. CMV was present in fewer copies than VZV in the vitreous. The retinal lesion clinically improved rapidly only by acyclovir. According to the clinical findings and the clinical responses to acyclovir, CMV seems not to cause ARN in this case.

Conclusion: VZV and CMV DNA were detected in the vitreous of a patient with VZV ARN. CMV reactivation appeared to be asymptomatic.

Keywords: acute retinal necrosis, varicella-zoster virus, cytomegalovirus, polymerase chain reaction, immunocompetent patient

\section{Introduction}

Acute retinal necrosis (ARN) syndrome is clinically characterized by peripheral necrotizing retinitis, retinal arteritis, and a prominent inflammatory reaction in the vitreous and anterior chamber. ${ }^{1}$ The pathogenesis of $\mathrm{ARN}$ is presumed to be associated with herpes virus infection, varicella-zoster virus (VZV), herpes simplex virus (HSV), cytomegalovirus (CMV), or Epstein-Barr virus (EBV). ${ }^{2}$ Polymerase chain reaction (PCR) is a sensitive and specific method for detecting viral DNA and is usually performed to assist in the diagnosis of ARN from the vitreous or the aqueous humor. ${ }^{3}$

Herpes zoster ophthalmicus has been linked to VZV reactivation within the trigeminal ganglion, and asymptomatic viral shedding of VZV from saliva and tear fluid has been reported. ${ }^{4-6}$ However, asymptomatic viral shedding in patients with ARN has not been described. In the present case report, we simultaneously identified the VZV and CMV genomes in the aqueous humor, tears, saliva, and swabs of the auricular and forehead skin areas in sequential samples assessed by PCR in an otherwise healthy patient with ARN.

\section{Clinical course of the patient}

A 65-year-old otherwise healthy Japanese woman presented at another hospital with blurred vision in the left eye. The left eye showed inflammation in the anterior chamber 
and white patches in the posterior pole. She was given a full medical examination, and the results of blood tests, including angiotensin converting enzyme, syphilis test, chest X-ray, tuberculin skin test, and cerebrospinal fluid examination, were all within normal limits. The patient was referred to our hospital for further evaluation.

On initial examination, her decimal visual acuity on the left eye was 0.15 and her intraocular pressure was $13 \mathrm{mmHg}$. On examination, there were $2+$ aqueous cells in the anterior chamber and mutton-fat keratic precipitates, and the following were also observed: $3+$ vitreous cells, vasculitis in the temporal arcade, and white patches of retinal necrosis in the temporal part of the posterior pole and peripheral retina (Figure 1). Optical coherence tomography of the left macula showed a serous retinal detachment. The right eye was normal. According to these findings and the rapid progression of necrosis, a clinical diagnosis of ARN was made. Serum VZV, HSV, and CMV EIA-IgM antibody levels were not detected. Serum EIA-IgG antibody levels were HSV 4.0, VZV 35.2, and CMV 3.7 arbitrary units $\mathrm{mL}^{-1}$, respectively. HIV antigen-antibody test was negative and she had no previous history of diabetes mellitus, leukopenia, cytotoxic chemotherapy, corticosteroid use, or non-cytotoxic immunosuppressive medication use. Her full blood count, glucose, renal function, and liver function tests were within normal limits. We did not detect any abnormality by blood examinations or history. We therefore concluded that she was immunocompetent. There were no systemic symptoms and any skin changes similar to herpetic rash.
The patient was admitted to our hospital, and intravenous acyclovir $500 \mathrm{mg}$ three times a day, oral prednisone $40 \mathrm{mg} /$ day, and aspirin $100 \mathrm{mg}$ /day were given. Fundus examination was difficult due to the severe vitreous opacity. Recent reports have described that prophylactic vitrectomy may help to eliminate inflammatory factors and reduce the incidence of retinal detachment; ${ }^{7,8}$ we therefore performed prophylactic vitrectomy, entire circumferential scleral buckling, silicone oil tamponade, and cataract surgery on day 2 of admission. The undiluted vitreous was sampled from the patient at the beginning of the vitrectomy and tested by PCR. The results of the PCR of vitreous were positive for VZV and CMV and negative for HSV, EBV, and human herpes virus 6 and 7 (Figure 2).

Although CMV was positive, there were fewer copies than for VZV, and since the patient was otherwise healthy, we continued treatment with intravenous acyclovir. Although the patient was given only acyclovir, the white patches gradually disappeared or cicatrized (Figure 3). An intravenous acyclovir dose of $500 \mathrm{mg}$ three times a day was given for 12 days. On day 12 of admission, the visual acuity of the left eye improved to 0.3 and the intraocular pressure was $10 \mathrm{mmHg}$. The treatment was later changed to oral valacyclovir $1,000 \mathrm{mg}$, three times a day for 3 months, and oral prednisone was tapered slowly over 3 months. At 1 month after hospitalization, rhegmatogenous retinal detachment of the peripheral retina occurred and a reoperation was performed. There was neither a new focus of infection nor a relapse of inflammation following the reoperation. At the end of the follow up, the visual acuity of the left eye was 0.1 and intraocular pressure was $12 \mathrm{mmHg}$. The right eye was normal.

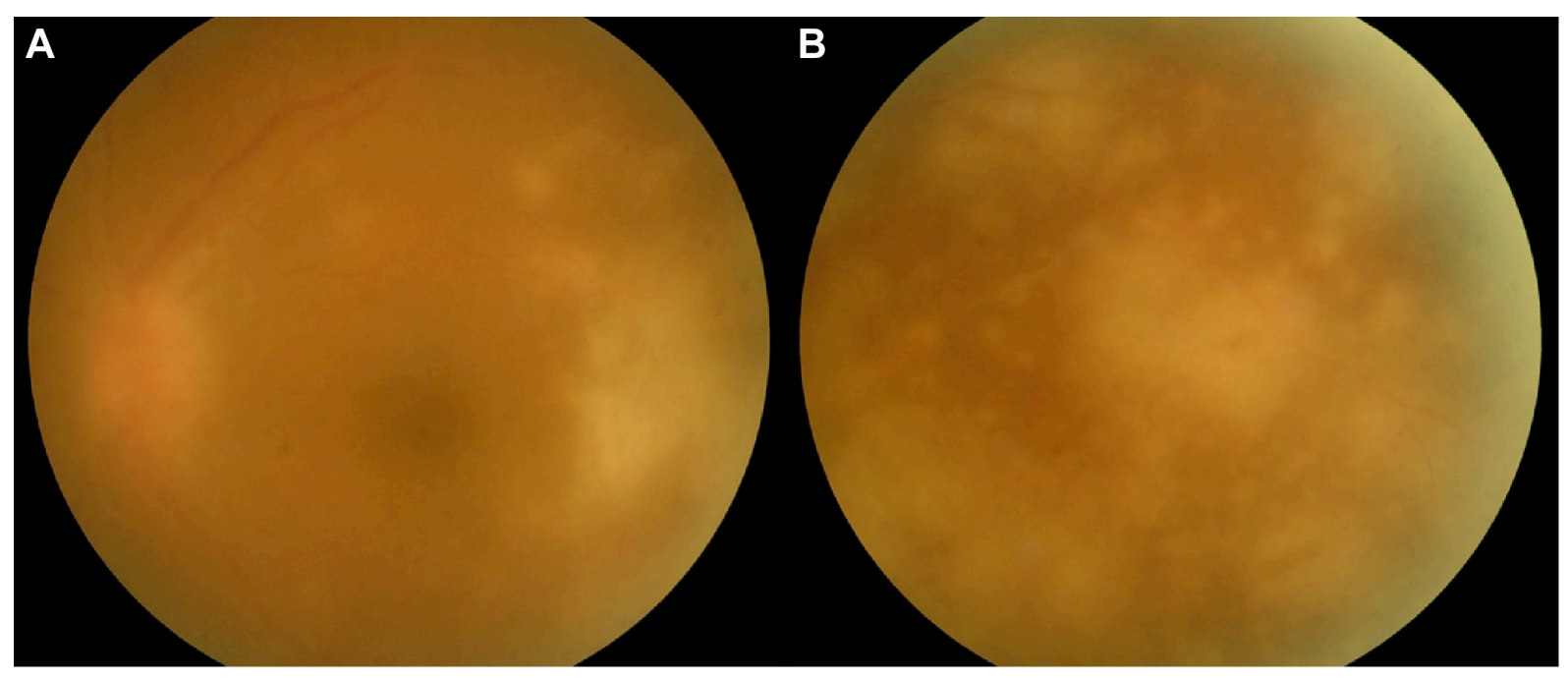

Figure I Fundus photographs of the left eye of the patient upon presentation at our hospital.

Notes: The photographs revealed multiple areas of confluent necrotizing retinitis and occlusive vasculitis at the posterior pole $(\mathbf{A})$ and the temporal periphery $(\mathbf{B})$ with overlying vitritis consistent with acute retinal necrosis. 

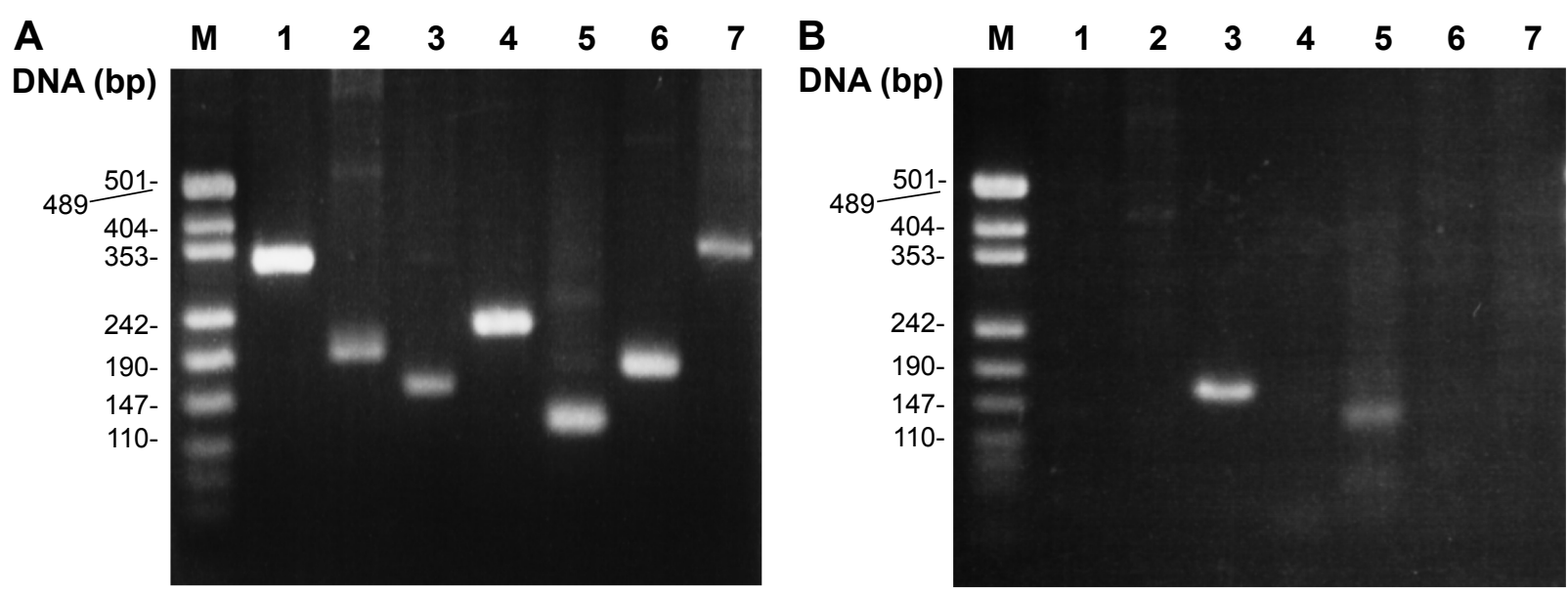

Figure 2 Agarose gel electrophoresis of the PCR products from vitreous.

Notes: Positive controls (A) and vitreous sample from the patient (B). Lane I: HSV-I; lane 2: HSV-2; lane 3: VZV; lane 4: EBV; lane 5: CMV; lane 6: HHV-6A/B; and lane 7: HHV-7. VZV and CMV were detected (B).

Abbreviations: PCR, polymerase chain reaction; HSV, herpes simplex virus; VZV, varicella-zoster virus; EBV, Epstein-Barr virus; CMV, cytomegalovirus; HHV, human herpes virus.

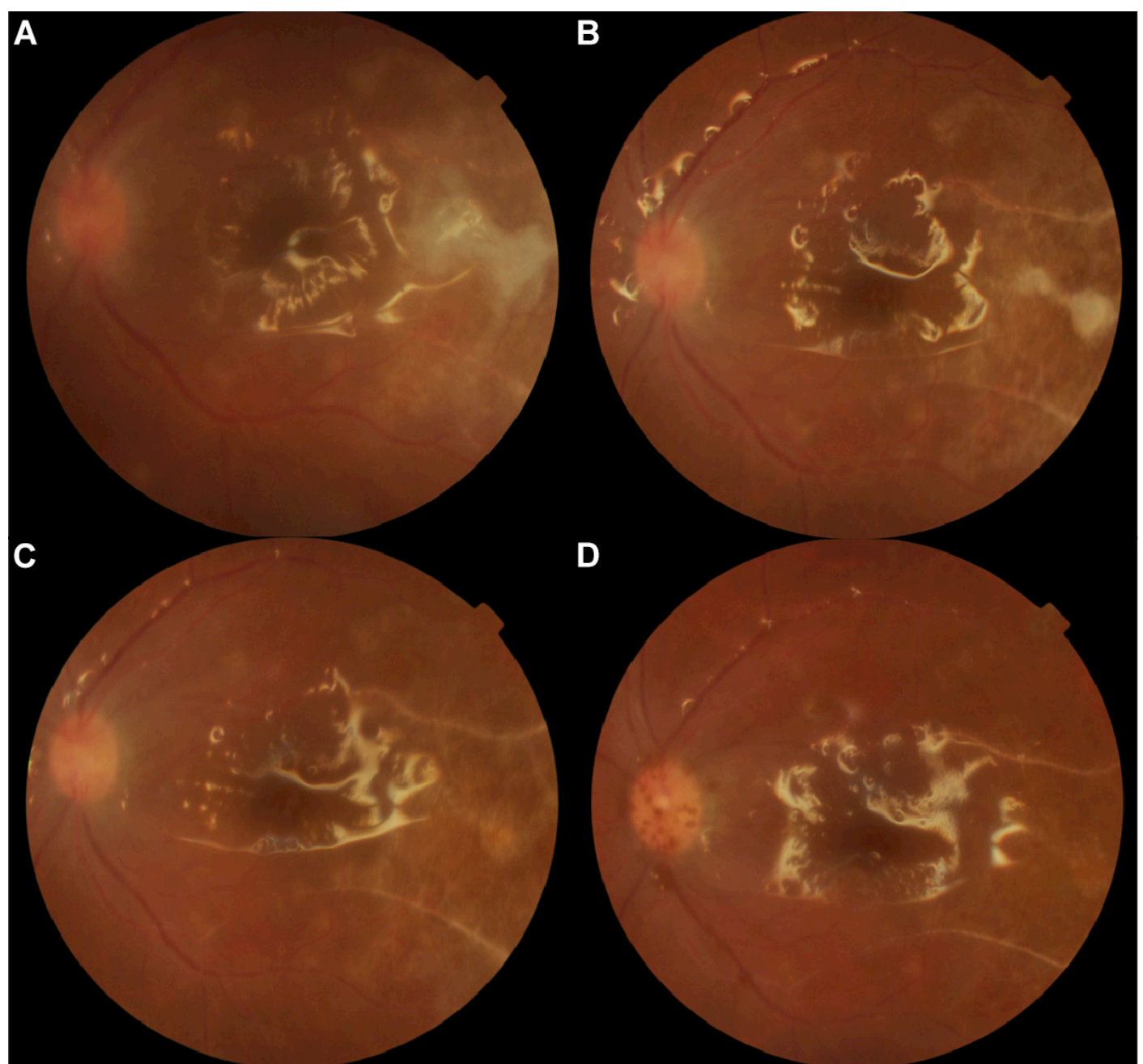

Figure 3 Gradual resolution of the retinitis and occlusive vasculitis with treatment.

Notes: Gradual resolution of the retinitis and occlusive vasculitis with treatment (silicon oil in situ): day 2 (A), day 5 (B), day 8 (C), and day 20 (D) after admission to our hospital. 


\section{Sample collection and DNA analyses}

Vitreous was obtained during vitrectomy. Tears and saliva were collected using Schirmer test papers and cotton, respectively. Swabs of the auricular and forehead skin areas and tears were collected bilaterally and sequentially, and PCR was performed at various time points during the treatment period.

Nucleic acid from clinical samples was extracted and purified using a QIAamp DNA blood mini kit (Qiagen NV, Venlo, the Netherlands) for amplification of the HSV-1, HSV-2, VZV, EBV, CMV, HHV (human herpes virus)-6, and HHV-7 gene by PCR, as described previously. ${ }^{6,9,10}$ PCR analysis was performed using the primer pairs shown in Table 1.

The results of PCR are shown in Table 2. The VZV genomes were detected in the vitreous and saliva, and the swabs of the auricular and forehead skin areas. The left eye was affected and the viral copy numbers were more abundant in the tears and skin taken from the ipsilateral side than in those from the contralateral side on days 2-5, although the difference decreased with time. The CMV genome was identified in the vitreous. CMV was detected in the tears, saliva, and skin from the initial samples with an increasing copy number on day 8 and later, but no corneal or skin lesions were observed over the observation period.

\section{Discussion}

ARN is caused by HSV and VZV in otherwise healthy patients and by CMV in immunosuppressed patients, but simultaneous detection of CMV has not been reported in patients with either HSV-induced ARN or VZV-induced ARN. Lau et al reported that the EBV-positive eyes of their patients were also positive for VZV.${ }^{11}$ To our knowledge, this is the first case report of simultaneous detection of CMV in a patient with VZV-induced ARN.

Ocular CMV infections usually present as anterior uveitis. ${ }^{12}$ ARN is usually caused by VZV and HSV, and more rarely by CMV in some immunocompetent patients. ${ }^{2}$ Tajunisah et al reported the case of an immunocompetent patient with CMV ARN in whom the vitreous tap was positive for CMV without detecting VZV and HSV. ${ }^{13}$ In their case, the patient had anterior chamber inflammation, marked vitritis, and anterior retinal necrosis. Initially, they treated the patient with $500 \mathrm{mg}$ of intravenous acyclovir three times daily, but the necrotic retinitis lesions enlarged. They then replaced the acyclovir with ganciclovir, and the necrotizing retinitis lesions regressed. Schneider et al presented five cases of CMV necrotizing retinitis in nonHIV patients. ${ }^{14}$ They described that the cases had both characteristic ARN and classic CMV retinitis, in addition to panretinal occlusive vasculitis, moderate intraocular inflammation, and slowly progressive granular retinitis. These cases were treated with ganciclovir or valganciclovir, but they required prolonged antiviral therapy to achieve a complete resolution of retinitis, which contrasts with the rapid treatment response normally observed in the cases of ARN caused by HSV or VZV.

\section{Conclusion}

In our case, the patient had inflammation in the anterior chamber, vitritis, occlusive vasculitis, and retinal necrosis in the temporal region of the posterior pole and the peripheral retina. The retinal necrosis expanded within 1 week, unlike the slowly progressive retinitis described by Schneider et al. ${ }^{14}$ Although previous studies of CMV

Table I List of primers for the amplification of various herpes viruses

\begin{tabular}{|c|c|c|c|}
\hline Virus & Direction & Sequences $\left(5^{\prime}-3^{\prime}\right)$ & Product size (bp) \\
\hline HSV-I & $\mathrm{F}$ & CGTGATTTTGTTTGTCGTCATAG & 333 \\
\hline HSV-I & $\mathrm{R}$ & GTCAGGTTGTAGGGTTGTTTCC & \\
\hline HSV-2 & $\mathrm{F}$ & CTAGTTGTCGCGGTGGGACT & 212 \\
\hline HSV-2 & $\mathrm{R}$ & TAGTACACAGTGATCGGGATGC & \\
\hline VZV & $\mathrm{F}$ & TCCGACATGCAGTCAATTTCAACGTC & 161 \\
\hline VZV & $\mathrm{R}$ & GGTCGGGTAGACGCTACCACTCGTTT & \\
\hline EBV & $\mathrm{F}$ & CTTAGAATGGTGGCCGGGATGTAAAAT & 229 \\
\hline EBV & $\mathrm{R}$ & ATCCAGTACGTCTTTGTGGAGCCCAAG & \\
\hline HCMV & $\mathrm{F}$ & GCGCGTACCGTTGAAAGAAAAGCATAA & $13 \mid$ \\
\hline HCMV & $\mathrm{R}$ & TGGGCACTCGGGTCTTCATCTCTTTAC & \\
\hline $\mathrm{HHV}-6 \mathrm{~A} / \mathrm{B}$ & $\mathrm{F}$ & ATGCGCCATCATAATGCTCGGATACA & 183 \\
\hline $\mathrm{HHV}-6 \mathrm{~A} / \mathrm{B}$ & $\mathrm{R}$ & СССTGCATTCTTACGGAAGCAAAACG & \\
\hline HHV-7 & $\mathrm{F}$ & GCCCGTTTTCGGAAATATTGGAGAGAT & 347 \\
\hline $\mathrm{HHV}-7$ & $\mathrm{R}$ & ACGCACGAGACGCACTTTTCTTAAACA & \\
\hline
\end{tabular}

Abbreviations: HSV, herpes simplex virus; VZV, varicella-zoster virus; EBV, Epstein-Barr virus; HCMV, human cytomegalovirus; HHV, human herpes virus; F, forward; $\mathrm{R}$, reverse; bp, base pair. 
Table 2 Systemic therapy and results of polymerase chain reaction

\begin{tabular}{|c|c|c|c|c|c|c|c|c|c|c|}
\hline Day & 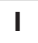 & 2 & 4 & 5 & 8 & 10 & 13 & 16 & 20 & 30 \\
\hline \multicolumn{7}{|c|}{ Oral prednisone $40 \mathrm{mg} /$ day } & \multicolumn{4}{|c|}{ Oral prednisone $30 \mathrm{mg} / \mathrm{day}$} \\
\hline \multicolumn{7}{|c|}{ Intravenous acyclovir I,500 mg/day } & \multicolumn{4}{|c|}{ Oral valacyclovir $3,000 \mathrm{mg} /$ day } \\
\hline \multicolumn{11}{|l|}{ Vitreous } \\
\hline VZV & ++ & & & & & & & & & ND \\
\hline CMV & + & & & & & & & & & ++ \\
\hline \multicolumn{11}{|l|}{$\mathrm{R}$ tear } \\
\hline VZV & & + & ND & ND & + & + & ND & ND & ND & \\
\hline CMV & & + & ND & + & ++ & + & ++ & ++ & ++ & \\
\hline \multicolumn{11}{|c|}{ R skin (auricular) } \\
\hline VZV & & + & ND & + & ND & + & ND & ND & + & \\
\hline CMV & & ND & ++ & ND & + & ++ & + & ND & ++ & \\
\hline \multicolumn{11}{|c|}{ R skin (forehead) } \\
\hline VZV & & ND & + & ++ & + & ND & ND & ND & ND & \\
\hline CMV & & + & ++ & ND & +r++ & ++ & + & ND & + & \\
\hline \multicolumn{11}{|l|}{$L$ tear } \\
\hline VZV & & +++ & ND & ND & + & ND & + & ND & + & \\
\hline CMV & & + & ND & ND & ++ & ++ & ++ & ++ & ++ & \\
\hline \multicolumn{11}{|c|}{ L skin (auricular) } \\
\hline VZV & & ++ & + & + & ND & ND & + & + & ND & \\
\hline CMV & & + & ND & ND & ++ & ++ & + & + & ++ & \\
\hline \multicolumn{11}{|c|}{ L skin (forehead) } \\
\hline VZV & & + & ND & + & + & + & ND & ND & ND & \\
\hline CMV & & + & ND & ND & ++ & ND & + & + & + & \\
\hline \multicolumn{11}{|l|}{ Saliva } \\
\hline VZV & & ++ & + & + & + & + & ND & + & ++ & \\
\hline CMV & & ++ & ND & ND & ++ & ++ & ++ & + & ++ & \\
\hline
\end{tabular}

Notes: ++++, I,000 copy/2 $\mu \mathrm{L} ;+++$, I00-I,000 copy/2 $\mu \mathrm{L} ;++$, I0-100 copy/2 $\mu \mathrm{L} ;+$, I-10 copy/2 $\mu \mathrm{L} ;$ ND, <I copy/2 $\mu \mathrm{L}$.

Abbreviations: VZV, varicella-zoster virus; CMV, cytomegalovirus; $R$, right; L, left.

necrotizing retinitis have reported successful treatment with ganciclovir or valganciclovir, in our patient the retinal lesion was improved only by acyclovir, which elicited a rapid treatment response. In consideration of these clinical findings and the responses to acyclovir, we conclude that CMV did not contribute to the pathogenesis of ARN in this case. As shown in Table 2, the viral DNA was detected by PCR even during antiviral therapy. The inhibition of DNA replication might not have been complete in the infected cells because the inhibition of DNA synthesis depends on the ratio between synthesized guanosine triphosphate and incorporated acyclovir triphosphate.

VZV DNA was detected in the vitreous, tears, saliva, and skin, indicating that VZV reactivation occurred in the tears, saliva, and skin of the auricular and forehead regions, a broad area of the skin and mucous membranes of the face, as shown in Table 2. Since the patient did not present any lesions related to VZV or CMV except in the left eye, asymptomatic shedding of VZV and CMV might have occurred in the facial area. If so, such shedding might suggest that some stimuli caused viral reactivation in the various ganglia focusing on the left trigeminal ganglion.
We could not find any specific trigger in the patient history, but we simultaneously detected VZV and CMV in the vitreous and in the facial area in the patient with VZV-induced ARN. However, while the VZV reactivation caused ARN in the left eye, it caused no skin lesions. The cause of the VZV reactivation was unclear, although it might have been due to a breakdown of the immune system. CMV reactivation appeared to be asymptomatic both in the eye and other lesions. This suggests that asymptomatic reactivation of VZV and CMV might occur in patients with ARN.

\section{Disclosure}

The authors report no conflicts of interest in this work.

\section{References}

1. Holland GN. Standard diagnostic criteria for the acute retinal necrosis syndrome. Executive Committee of the American Uveitis Society. Am J Ophthalmol. 1994;117(5):663-667.

2. Guex-Crosier Y, Rochat C, Herbort CP. Necrotizing herpetic retinopathies. A spectrum of herpes virus-induced diseases determined by the immune state of the host. Ocul Immunol Inflamm. 1997;5(4): 259-265.

3. Tran TH, Rozenberg F, Cassoux N, Rao NA, LeHoang P, Bodaghi B. Polymerase chain reaction analysis of aqueous humour samples in necrotising retinitis. Br J Ophthalmol. 2003;87(1):79-83. 
4. Mehta SK, Cohrs RJ, Forghani B, Zerbe G, Gilden DH, Pierson DL. Stress-induced subclinical reactivation of varicella zoster virus in astronauts. J Med Virol. 2004;72(1):174-179.

5. Cohrs RJ, Mehta SK, Schmid DS, Gilden DH, Pierson DL. Asymptomatic reactivation and shed of infectious varicella zoster virus in astronauts. J Med Virol. 2008;80(6):1116-1122.

6. Miyakoshi A, Takemoto M, Shiraki K, Hayashi A. Varicella-zoster virus keratitis with asymptomatic conjunctival viral shedding in the contralateral eye. Case Rep Ophthalmol. 2012;3(3):343-348.

7. Hillenkamp J, Nölle B, Bruns C, Rautenberg P, Fickenscher H, Roider J. Acute retinal necrosis: clinical features, early vitrectomy, and outcomes. Ophthalmology. 2009;116(10):1971-1975.

8. Luo YH, Duan XC, Chen BH, Tang LS, Guo XJ. Efficacy and necessity of prophylactic vitrectomy for acute retinal necrosis syndrome. Int J Ophthalmol. 2012;5(4):482-487.

9. Tanaka T, Kogawa K, Sasa H, Nonoyama S, Furuya K, Sato K. Rapid and simultaneous detection of 6 types of human herpes virus (herpes simplex virus, varicella-zoster virus, Epstein-Barr virus, cytomegalovirus, human herpes virus $6 \mathrm{~A} / \mathrm{B}$, and human herpes virus 7) by multiplex PCR assay. Biomed Res. 2009;30(5):279-285.
10. Durzynska J, Pacholska-Bogalska J, Kaczmarek M, et al. Multiplex PCR for identification of herpes virus infections in adolescents. $J$ Med Virol. 2011;83(2):267-271.

11. Lau CH, Missotten T, Salzmann J, Lightman SL. Acute retinal necrosis features, management, and outcomes. Ophthalmology. 2007; 114(4):756-762.

12. Chee SP, Bacsal K, Jap A, Se-Thoe SY, Cheng CL, Tan BH. Clinical features of cytomegalovirus anterior uveitis in immunocompetent patients. Am J Ophthalmol. 2008;145(5):834-840.

13. Tajunisah I, Reddy SC, Tan LH. Acute retinal necrosis by cytomegalovirus in an immunocompetent adult: case report and review of the literature. Int Ophthalmol. 2009;29(2):85-90.

14. Schneider EW, Elner SG, van Kuijk FJ, et al. Chronic retinal necrosis: cytomegalovirus necrotizing retinitis associated with panretinal vasculopathy in non-HIV patients. Retina. 2013;33(9):1791-1799.
Clinical Ophthalmology

\section{Publish your work in this journal}

Clinical Ophthalmology is an international, peer-reviewed journal covering all subspecialties within ophthalmology. Key topics include: Optometry; Visual science; Pharmacology and drug therapy in eye diseases; Basic Sciences; Primary and Secondary eye care; Patient Safety and Quality of Care Improvements. This journal is indexed on

\section{Dovepress}

PubMed Central and CAS, and is the official journal of The Society of Clinical Ophthalmology (SCO). The manuscript management system is completely online and includes a very quick and fair peer-review system, which is all easy to use. Visit http://www.dovepress.com/ testimonials.php to read real quotes from published authors. 